\title{
Hypoxic Microenvironment and Metastatic Bone Disease
}

\section{Toru Hiraga}

Department of Histology and Cell Biology, Matsumoto Dental University, 1780 Gobara-Hirooka, Shiojiri, Nagano 399-0781, Japan; bone.mets@gmail.com; Tel.: +81-263-51-2225

Received: 25 October 2018; Accepted: 7 November 2018; Published: 9 November 2018

check for updates

\begin{abstract}
Hypoxia is a common feature of solid tumors and is associated with an increased risk of metastasis and a poor prognosis. Recent imaging techniques revealed that bone marrow contains a quite hypoxic microenvironment. Low oxygen levels activate hypoxia signaling pathways such as hypoxia-inducible factors, which play critical roles in the key stages of metastatic dissemination including angiogenesis, epithelial-mesenchymal transition, invasion, maintenance of cancer stem cells, tumor cell dormancy, release of extracellular vesicles, and generation of pre-metastatic niches. Hypoxia also affects bone cells, such as osteoblasts and osteoclasts, and immune cells, which also act to support the development and progression of bone metastases. Paradoxically, hypoxia and related signaling molecules are recognized as high-priority therapeutic targets and many candidate drugs are currently under preclinical and clinical investigation. The present review focuses on our current knowledge of the potential roles of hypoxia in cancer metastasis to bone by considering the interaction between metastatic cancer cells and the bone microenvironment. Current therapeutic approaches targeting hypoxia are also described.
\end{abstract}

Keywords: hypoxia; hypoxia-inducible factors; bone metastasis

\section{Introduction}

Bone is one of the most common sites of cancer metastasis [1,2]. The majority of patients (around $70 \%$ ) with breast and prostate cancers and a substantial proportion of patients $(30-40 \%)$ with lung cancer eventually develop bone metastases [2]. Although bone metastases, per se, are rarely responsible for cancer mortality, they are associated with significant morbidity by causing so-called skeletal-related events (SREs), including hypercalcemia, pathological fractures, spinal compression, and bone pain, indirectly leading to poor prognoses [2]. Therefore, the control of bone metastasis is a critical component in cancer treatment. However, the mechanisms of bone metastasis have not been fully elucidated.

In addition to genetic and epigenetic events, the microenvironment impacts cancer progression and metastasis through a variety of mechanisms. Hypoxia, a condition of low oxygen tension, is a hallmark of tumor microenvironments, which is caused by an imbalance between oxygen delivery and consumption [3]. Intratumoral hypoxia is associated with a significantly increased risk of metastasis and poor prognosis in cancer patients [4].

Several lines of evidence suggest that transcription factors hypoxia-inducible factors (HIFs), mediate the primary response to hypoxia [4,5]. HIFs are composed of an oxygen-sensitive $\alpha$ subunit (HIF- $\alpha$ ) and a stable $\beta$ subunit (HIF-1 $\beta$ ). In mammals, three genes that encode HIF- $\alpha$ subunit proteins have been identified. HIF- $1 \alpha$ and HIF- $2 \alpha$ are broadly expressed in many human cancers, whereas little is known about HIF-3 $\alpha[4,6]$. Under normoxic conditions, HIF- $\alpha$ subunits are continuously degraded by the ubiquitin-proteasome pathway. In contrast, under hypoxic conditions, HIF- $\alpha$ subunits are stabilized, translocate to the nucleus, dimerize with HIF-1 $\beta$, and initiate gene transcription by binding 
to hypoxia response elements (HREs). In addition to hypoxia, HIF- $\alpha$ subunits were shown to be regulated by several non-hypoxic stimuli involving kinases and reactive oxygen species [7].

In this article, the most recent understanding of the role of a hypoxic microenvironment in the development and progression of bone metastases is reviewed and discussed.

\section{Basic Understanding of the Pathophysiology of Bone Metastasis}

Once cancer cells metastasize to bone, they disrupt the physiological bone metabolism maintained by osteoblasts and osteoclasts and establish a new cellular environment more favorable for the progression of bone metastasis, the so-called "vicious cycle" [1]. In brief, osteoclast stimulating factors, such as parathyroid hormone-related protein (PTHrP), secreted by metastatic cancer cells activate bone destruction, leading to an increase in the release of bone-derived growth factors, including insulin-like growth factors (IGFs) and transforming growth factor $\beta$ (TGF $\beta$ ), into the bone microenvironment. These factors then act on cancer cells, thereby causing more aggressive cancer phenotypes and further bone destruction. This theory suggests that osteoclasts play pivotal roles in the process of bone metastasis.

\section{Hypoxia and Cancer Metastasis}

Accumulating evidence indicates that hypoxia enhances malignant phenotypes of cancer cells through enhancing angiogenesis, epithelial-mesenchymal transition (EMT), invasion, cancer stem-like phenotypes, tumor cell dormancy, release of extracellular vesicles (EVs), and generation of pre-metastatic niches, most of which are HIFs-dependent and all of which are positively correlated with cancer metastasis (Figure 1) [5,8].

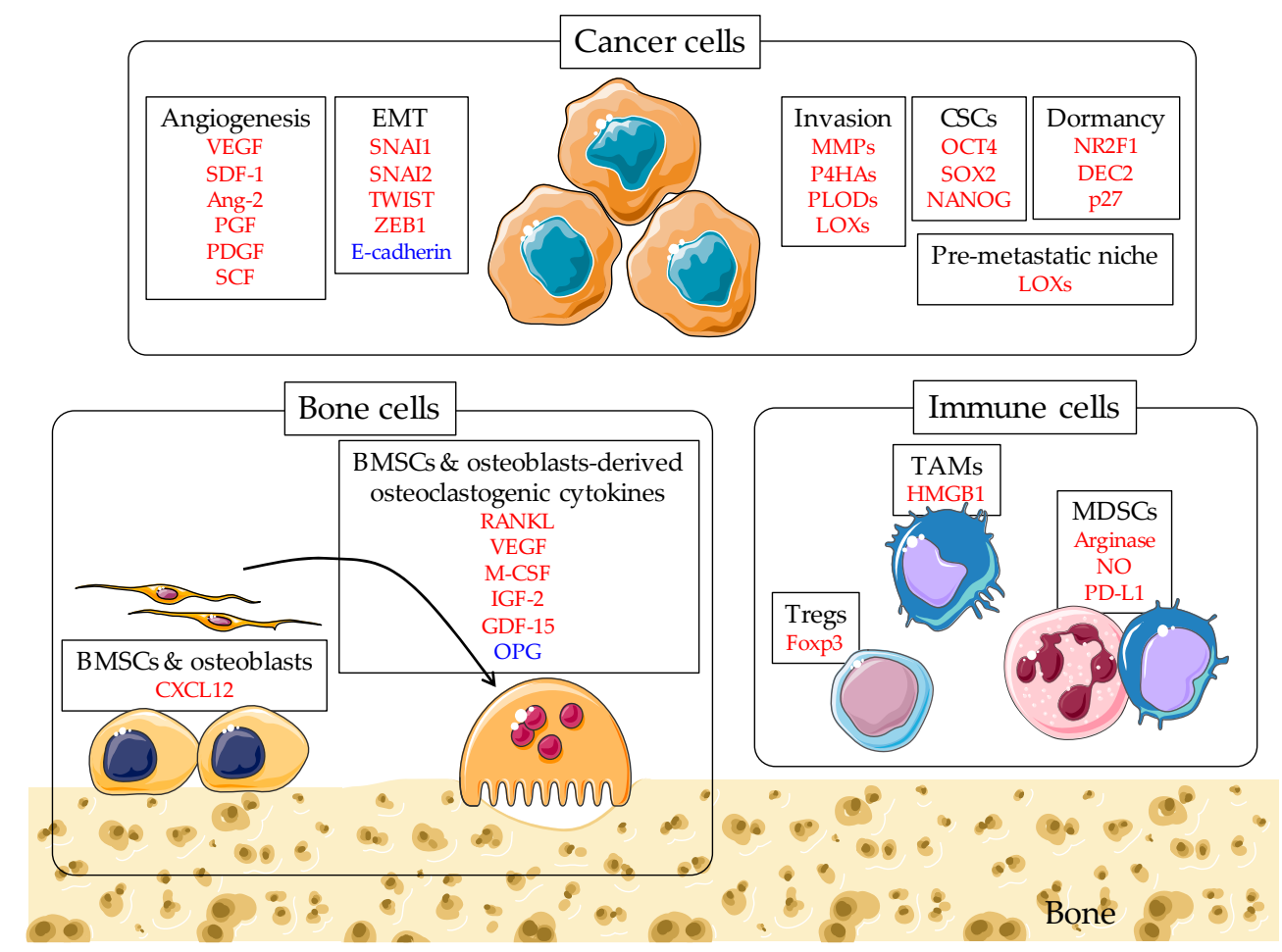

Figure 1. Hypoxic signaling in the bone-metastatic cascade. The figure summarizes hypoxia-induced and hypoxia inducible factor (HIF)-target genes involved in the key stages of the bone-metastatic cascade. Upregulated genes are shown in red and downregulated genes are in blue. Images adapted from Servier Medical Art (https:/ / smart.servier.com/). 


\subsection{Angiogenesis}

Because one of the reasons for hypoxia caused in solid tumors is compromised blood flow, angiogenesis is an adaptive response, which stimulates $\mathrm{O}_{2}$ delivery and supports tumor growth. HIFs function as master regulators of angiogenesis by upregulating the expression of genes involved in angiogenic responses, such as vascular endothelial growth factor (VEGF), stromal-derived factor-1 (SDF-1), angiopoietin-2 (Ang-2), placental growth factor (PGF), platelet-derived growth factor (PDGF), and stem cell factor (SCF) [5]. It has been well-described that angiogenesis is essential for cancer metastasis [9]. There have also been several reports showing the relationship between angiogenesis and bone metastasis. A preclinical study showed that the angiogenesis inhibitor TNP-470 suppressed bone metastases of MDA-MB-231 human breast cancer cells [10]. The study, using clinical samples of breast cancer, revealed that the microvessel density in the primary tumors had a strong correlation with the occurrence of bone metastases [11].

\subsection{EMT}

EMT is the transition of epithelial cells to cells with mesenchymal phenotypes [12]. It has been demonstrated that HIF-1 downregulates E-cadherin, a specific marker for epithelial cells, by enhancing the expression of so-called EMT-activating transcription factors, including SNAI1, SNAI2, TWIST, and ZEB1 [5,8]. Although the relationship with hypoxia and HIFs was not determined, the overexpression of TWIST1 was shown to facilitate the development of bone metastases of MDA-MB-231/B02 human breast cancer cells in mice through a mechanism dependent on microRNA-10b (miR-10b) [13]. Liu et al. reported that the expression of ZEB1 in bone-metastatic small cell lung cancer (SCLC) tissues and cell lines was higher than that in non-metastatic ones [14]. They also demonstrated that ZEB1 knockdown and ZEB1 overexpression inhibited and promoted bone metastases of SBC-3 and SBC-5 human SCLC cells in mice, respectively [14].

\subsection{Invasion}

The local invasion of tumor cells from the primary tumors to the adjacent stroma is a first step in the metastasis cascade. The degradation of extracellular matrix (ECM) is one of the mechanisms that tumor cells utilize to accelerate the invasion. Several proteinases are involved in this process. Among these enzymes, the expression of matrix metalloproteinases (MMPs), including MMP2, MMP9 and MMP14, are regulated by HIFs [5]. HIFs also modulate ECM remodeling through increased expression of prolyl-4-hydroxylases (P4HA1 and P4HA2), procollagen-lysine,2-oxyglutarate 5-dioxygenases (PLOD1 and PLOD2), and lysyl oxidases (LOX, LOXL2, and LOXL4), which are required for cancer cell invasion [5].

\subsection{Cancer Stem Cells (CSCs)}

The cancer stem cell (CSC) hypothesis proposes that only a small fraction of tumor cells have tumor-initiating potential and are able to self-renew and differentiate into the heterogeneous cell populations that compose tumors [15]. These stem-like properties are required to initiate secondary tumor formation in distant organs. Our preclinical studies demonstrated that cancer stem-like phenotypes contribute to the development of bone metastases of human breast cancer MDA-MB-231 cells [16] and mouse breast cancer 4T1 and Jyg-MC(A) cells [17] in mice.

Hypoxia was shown to induce the cancer stem-like phenotypes in an HIF-dependent manner firstly in glioma [18] and, subsequently, in several types of cancer, including breast cancer [19]. Hypoxia and HIFs promote the generation and maintenance of CSCs through the expression of genes, including octamer-binding transcription factor 4 (OCT4), sex determining region Y-box 2 (SOX2), and NANOG [20]. 


\subsection{Dormancy}

Tumor dormancy is defined as a temporary mitotic and growth arrest, which might explain local recurrences and metastases at different time points after treatment [21]. Metastases originate from disseminated tumor cells (DTCs), which often undergo a period of dormancy [22]. Bone marrow is one of the most frequent sites in which DTCs are detected [21]. In this case, bone can be a target organ of metastasis, but it might also serve as a transit site from which cells can again disseminate to their final metastatic organs.

It has been suggested that tumor cell dormancy is regulated by hypoxia. Fluegen et al. showed that hypoxic microenvironments upregulate key dormancy genes, such as NR2F1, DEC2, and $p 27$, in head and neck and breast cancer cells in mice and humans, which was accompanied by the overexpression of HIF-1 and glucose transporter 1 (GLUT1) [23]. Furthermore, post-hypoxic DTCs become quiescent in metastatic sites and evade chemotherapy. Another group reported that several cycles of hypoxia and re-oxygenation generate a hypoxia-resistant cell line, which can survive under hypoxic conditions by entering into a dormant state that is reversible upon normoxia exposure [24]. In contrast, Johnson et al. proposed the opposite effects of hypoxia on tumor cell dormancy in bone marrow [25]. They revealed that leukemia inhibitory factor receptor (LIFR)-signal transducer and activator 3 (STAT3)-suppressor of cytokine signaling 3 (SOCS3) signaling in DTCs confers a dormancy phenotype in response to LIF, a member of the IL- 6 family of cytokines and produced by osteoblast-lineage and bone marrow stromal cells. The pathway is inhibited by hypoxia and HIF signaling, leading to the transition from a dormant to an invasive phenotype. Further studies are required to clarify the complex relationships between hypoxia and tumor cell dormancy.

\subsection{Extracellular Vesicles (EVs)}

EVs, including exosomes (30-100 nm diameter) and microvesicles (100-1000 nm diameter), are cell-derived vesicles, which are now recognized as major players in cell-cell communication [26]. Cancer-associated EVs also promote angiogenesis, CSCs, EMT, and metastasis through their content, such as various types of proteins, RNAs, and DNAs. EVs derived from prostate cancer (PC3), myeloma (U266, MM1S, and OPM2), and lung cancer (CRL-2868) cells were shown to stimulate osteoclast formation [27-29], whereas those from prostate cancer (TRAMP-C1) cells inhibited osteoclast formation [30]. Exosomes derived from bone marrow stromal cells (BMSCs) in multiple myeloma facilitated tumor growth, which was inhibited by exosomes from normal BMSCs [31]. Another report revealed that exosomes from BMSCs promoted dormancy in metastatic breast cancer cells by exosomal transfer of miRs [32]. Furthermore, Hashimoto et al. showed that exosomes from prostate cancer cells containing hsa-miR-940 induced bone metastases with an osteoblastic phenotype [33]. These findings imply the presence of exosome-mediated complex cell-cell communication in the bone metastatic microenvironment.

It has been reported that hypoxia increases the release of EVs from cancer cells [34]; however, the contribution to metastatic bone diseases remains to be investigated.

\subsection{Pre-Metastatic Niche}

The pre-metastatic niche, a favorable microenvironment created in secondary organs for subsequent metastases, is formed mainly by primary tumor-derived factors, tumor-mobilized bone marrow-derived cells (BMDCs), and local stromal components [35]. Recent studies revealed that the LOX family members, including LOX, LOXL2, and LOXL4, are key HIF-1-regulated genes involved in BMDC recruitment to promote pre-metastatic niche formation [36]. LOX has also been shown to play a role in the formation of pre-metastatic bone lesions, which will be described in detail in Section 6. 


\section{Hypoxia and Bone Cells}

According to a study in which partial pressure of oxygen $\left(\mathrm{pO}_{2}\right)$ in the calvariae of live mice was measured using two-photon phosphorescence lifetime microscopy, the absolute $\mathrm{pO}_{2}$ in bone marrow was $<32 \mathrm{mmHg}(4.2 \%)$ despite the high vascular density [37]. The heterogeneous $\mathrm{pO}_{2}$ in bone marrow was lowest in deeper perisinusoidal regions $(9.9 \mathrm{mmHg}, 1.3 \%)$. These data indicate that bone is a quite hypoxic microenvironment.

\subsection{Effects of Hypoxia on Osteoclasts}

Hypoxia was shown to increase osteoclast formation in vitro [38,39], which was supported by findings that hypoxia stimulates the production of pro-osteoclastogenic cytokines, such as receptor activator of nuclear factor- $\mathrm{KB}$ ligand (RANKL), VEGF, macrophage colony-stimulating factor (M-CSF), IGF-2, and growth differentiation factor-15 (GDF-15), and inhibits the production of osteoprotegerin (OPG), an inhibitor of osteoclast differentiation [40]. Furthermore, the report by Miyauchi et al. suggested that hypoxia-induced osteoclast differentiation is mediated, at least in part, by HIF- $1 \alpha$ [41]. They further proposed that HIF- $1 \alpha$ is required for osteoclast activation [41]. Several studies, including ours, demonstrated that acidosis caused by hypoxia also promoted osteoclast formation and activity, which was mediated by the up-regulation of RANKL and nuclear factor of activated T cells cytoplasmic 1 (NFATc1) [39,42]. Hypoxia most likely acts to enhance osteoclastic bone destruction and bone metastasis (Figure 1).

\subsection{Effects of Hypoxia on Osteoblasts}

In vitro studies showed that hypoxia exhibited inhibitory effects on the differentiation and bone-forming capacity of osteoblasts [39,43]. In contrast, mice with osteoblast-specific deletion of von Hippel-Lindau (VHL) and osteoblast-specific overexpression of HIF-1 $\alpha$ exhibited increased bone volume and osteoblast numbers [44,45], suggesting that hypoxia and HIF- $1 \alpha$ activation have positive effects on bone formation in vivo. Further studies are required to explain the discrepancy between in vitro and in vivo data.

A recent study by Devignes et al. demonstrated that activated HIF signaling in osteoblast-lineage cells promotes bone metastases in mice [46]. Mechanistically, they found that activation of HIF signaling in osteoprogenitor cells increased the production of $\mathrm{C}-\mathrm{X}-\mathrm{C}$ motif chemokine ligand 12 (CXCL12), which leads to an increase in proliferation and dissemination of breast cancer cells through direct activation of C-X-C motif chemokine receptor 4 (CXCR4), a receptor for CXCL12. Of note, these effects were also found in organs other than bone, such as lung, suggesting that HIF signaling in osteoblast-lineage cells might cause tumorigenesis beyond the local bone microenvironment (Figure 1).

\section{Hypoxia and Immune Cells in Bone}

Bone is a unique organ, which belongs not only to the musculoskeletal system but also to the immune system [47,48]. In bone, multiple types of immune cells and their progenitor cells share the same microenvironment with bone cells. Recent emerging evidence suggests the mutual relationship between bone and immune cells in their differentiation and function. Since 2000, the term "osteoimmunology" has been used to describe this discipline [49]. Thus, as well as cancer cells and bone cells, immune cells are one of the major players in metastatic bone lesions.

Malignant tumor cells have many mechanisms to make their microenvironment immunosuppressive, including the ability to suppress immune responses through immune check points, such as the cytotoxic T-lymphocyte antigen-4 (CTLA-4) and programmed cell death protein 1 (PD1) pathways [50]. In addition, hypoxia has recently been implicated as an important factor driving the immunosuppressive tumor microenvironment, which is created, at least in part, by the infiltration of immunosuppressive cells, such as tumor-associated macrophages (TAMs), 
myeloid-derived suppressor cells (MDSCs), and regulatory T (Treg) cells [51]. However, little is known about the involvement of these immune cells in bone metastasis (Figure 1).

\subsection{TAMs}

TAMs are macrophages infiltrating the tumor microenvironment. It has been demonstrated that the density of TAMs correlates with poor prognosis in several types of cancer [52]. TAMs can be divided into classically activated M1-like and alternatively activated M2-like subtypes [53]. M1-like TAMs are known to exert anti-tumor activity by promoting proinflammatory effects and immune responses. On the other hand, M2-like TAMs enhance tumor angiogenesis, matrix remodeling, tumor cell migration and invasion, and immunosuppression, resulting in tumor progression. TAMs isolated from established metastatic tumors are predominantly polarized to an M2-like phenotypes [53]. Several mediators, including interleukin-4 (IL-4) and IL-10, are involved in M2-like polarization. Huber et al. reported that hypoxia induced the secretion of high mobility group box-1 (HMGB1) from melanoma cells, which caused IL-10 production and M2-like TAM accumulation within the tumor [54], suggesting that hypoxia contributes to the conversion of TAMs to an immunosuppressive M2-like phenotype. Laoui et al. revealed that M2-like TAMs are preferentially attracted to hypoxic regions [55]. Furthermore, tumor-derived lactic acid, whose levels are elevated by hypoxic metabolism, promotes M2-like polarization in a HIF-1 $\alpha$-dependent manner [56]. These findings suggest that hypoxia is associated with the accumulation of M2-like TAMs and enhances immunosuppressive microenvironment. In addition, hypoxia is also shown to augment macrophage-mediated T-cell suppression in a manner dependent on HIF-1 $\alpha$ [57].

\section{2. $M D S C S$}

MDSCs are also tumor-infiltrating myeloid cells which impair immune responses through various mechanisms [58]. HIF- $1 \alpha$ has been reported to regulate the function and differentiation of MDSCs within the hypoxic tumor microenvironment [59]. According to Corzo et al., tumor-derived MDSCs possess higher immunosuppressive capacity than splenic MDSCs, which is mainly due to the HIF-1 $\alpha$-dependent induction of arginase activity and nitric oxide (NO) production [59]. Furthermore, Noman et al. showed that hypoxia upregulates the expression of programmed death-ligand 1 (PD-L1) in MDSCs and increases MDSC-mediated T cell tolerance [60].

\subsection{Tregs}

Tregs are a highly immunosuppressive fraction of $\mathrm{CD}^{+}$cells [61]. In tumors, Tregs exhibit activated phenotypes, including high expression of immune suppression-related molecules such as CTLA-4. Several studies reported that hypoxia is associated with the selective accumulation of Tregs in tumors, which not only suppresses antitumor responses but also promotes angiogenesis [62]. As a mechanism, hypoxia was shown to potently increase the expression of forkhead box P3 (Foxp3), a master regulator in the development and function of Tregs [63].

\section{Hypoxia, HIFs, and Bone Metastasis}

\subsection{Hypoxia and Bone Metastasis}

Intratumoral hypoxia is a common feature of cancers. According to Vaupel et al., overall median $\mathrm{pO}_{2}$ in cancers, including uterine cervix, head and neck, and breast cancers, was $10 \mathrm{~mm} \mathrm{Hg}$, which was markedly lower than that in normal tissues, which ranges from 24 to $57 \mathrm{~mm} \mathrm{Hg}$ [64]. Although the absolute values of $\mathrm{pO}_{2}$ in bone metastases in cancer patients are still unknown, our mouse study revealed the presence of pimonidazole-positive hypoxic regions in the bone metastases of MDA-MB-231 cells in nude mice [39]. Because pimonidazole accumulates in cells that have $\mathrm{pO}_{2}$ less than $10 \mathrm{mmHg}$ $(1.3 \%)$ [65], the result suggests that the hypoxic levels in bone metastases in this animal model are equivalent to those in human cancers [64]. 
As described in Section 3, hypoxia is closely associated with malignant behaviors of cancer cells. Consistent with this notion, our previous study demonstrated that a hypoxia-targeted agent, trans-activator of transcription (TAT)-oxygen-dependent degradation domain (ODD)-procaspase-3 (TOP3), whose details will be described in Section 7, significantly reduced bone metastases of MDA-MB-231 cells in mice [39]. Furthermore, as mentioned in Section 4, hypoxia and the resulting metabolic acidosis stimulate the differentiation of osteoclasts, key players in the vicious cycle of bone metastasis [1]. These data suggest the promoting roles of hypoxia in bone metastases; however, our study did not fully address whether or how hypoxia in primary tumors controls spontaneous metastasis to bone.

\subsection{HIFs and Bone Metastasis}

Gene expression analysis with cDNA microarrays showed that the expression of HIF- $1 \alpha$ was three-fold higher in primary tumors of breast cancer patients with bone micrometastases than in those without the micrometastases, which was associated with the down-regulation of genes responsible for HIF- $1 \alpha$ degradation, such as VHL and cullin-2 [66]. The results suggest that HIF- $1 \alpha$ may promote tumor dissemination to bone.

In our preclinical model, an immunohistochemical study confirmed the nuclear HIF- $1 \alpha$ expression in tumor cells in the bone metastases of MDA-MB-231 cells in nude mice, which co-localized or surrounded the pimonidazole-positive cells [39]. Furthermore, the stable expression of constitutive-active HIF- $1 \alpha$ increased and dominant-negative HIF- $1 \alpha$ decreased the development of bone metastases [39]. The results were confirmed by Lu et al.; although the effects were not specific to metastases to bone [67]. They also identified two genes, dual specificity protein phosphatase 1 (DUSP1) and CXCR4, as hypoxia-activated bone metastasis-associated genes.

PTHrP is a potent stimulator of osteoclastic bone destruction and bone metastasis [68]. Manisterski et al. revealed that hypoxia enhanced the expression of PTHrP in cancer cells mediated through HIF- $2 \alpha$ but not HIF- $1 \alpha$ [69]. It is well-known that PTHrP expression is also induced by TGF $\beta$, one of the growth factors abundantly stored in bone matrix and the key molecule in the vicious cycle of bone metastasis [1]. Dunn et al. reported that hypoxia and TGF $\beta$ regulate a common set of tumor genes, including PTHrP [70]. Furthermore, because inhibition of either pathway decreased bone metastases, with no further effect of double blockade, they proposed that hypoxia and TGF $\beta$ signaling drives bone metastases in parallel. Collectively, these results suggest the critical role of HIFs in bone metastases.

\subsection{Emerging Roles of Lysyl Oxidase (LOX) in Bone Metastasis}

LOX is a secreted copper-dependent amine oxidase, whose primary function is the covalent crosslinking of collagens and elastins in the ECM [71]. However, recent studies demonstrated that LOX also plays critical roles in hypoxia-induced cancer metastasis. Erler et al. firstly described that LOX expression is regulated by HIF-1 and the inhibition of LOX eliminates metastasis in mice [72]. Mechanistically, LOX increases cell motility through up-regulating focal adhesion kinase activity and cell-matrix adhesion. It was also revealed that LOX secreted by hypoxic cancer cells acts to form a pre-metastatic niche by recruiting $\mathrm{CD}_{11} \mathrm{~b}^{+}$myeloid cells [73].

It has also been reported that LOX plays critical roles in cancer cell colonization in bone. According to Cox et al., hypoxia is specifically associated with bone relapse in patients with estrogen receptor (ER)-negative breast cancer [74]. Their study using spontaneously metastasizing ER ${ }^{-}$ breast cancer 4T1 cells, which express high levels of LOX, demonstrated that inhibition of LOX by short hairpin RNA or anti-LOX antibody abrogates bone metastasis formation. Conversely, experiments using SW480, a non-metastatic colon cancer cell line with low LOX expression, showed that overexpression or systemic delivery of LOX leads to bone metastasis formation. These findings are further supported by the report by Reynaud et al.; however, the effects were independent of HIF-1 but dependent on LOX-driven IL-6 production [75]. They also revealed that LOX stimulates osteoclastogenesis and inhibits osteoblastogenesis [74,75]. Thus, it is most likely 
that LOX-induced disrupted bone homeostasis leads to the formation of focal pre-metastatic lesions in bone. Additionally, LOX is expressed in osteoblasts, which is induced by TGF $\beta$ released during bone resorption [76]. The findings fit naturally into the vicious cycle theory. These results collectively suggest the critical contribution of LOX to bone metastases. Thus, LOX could be a novel target for therapeutic intervention [77].

It is of interest that an in vitro study by Cox et al. showed that LOX stimulated osteoclast formation independently of RANKL, which was mediated through the direct action on NFATc1, the master regulator of osteoclastogenesis [74]; however, later studies failed to reproduce these findings $[75,78]$. There is a clear need for further study of the precise molecular mechanisms underlying LOX-driven osteoclastogenesis.

\section{Target Hypoxia}

Considering the critical contributions as described above, hypoxia and HIFs are promising therapeutic targets in treating bone metastases. One approach utilizes bioreductive or hypoxia-activated prodrugs (HAPs) to eradicate hypoxic cells $[79,80]$. Another strategy is the inhibition of HIFs and their downstream targets or upstream signaling molecules.

\subsection{HAPS}

HAPs are activated by enzymatic reduction at low oxygen tension. The majority of HAP metabolites result in DNA damage by interfering with DNA replication. Several HAPs, including AQ4N, PR-104, and TH-302 (evofosfamide), are currently undergoing clinical trials. Some other compounds, such as TOP3, are also under development. However, to date, there are only a few studies available that have investigated the effects on metastatic bone diseases.

\subsubsection{AQ4N}

AQ4N is enzymatically converted to a cytotoxic DNA-binding agent, AQ4, under hypoxic conditions. AQ4 non-covalently binds to DNA to facilitate anti-tumor activity and selectively inhibits the activity of the DNA separation enzyme topoisomerase II [81]. A phase I clinical trial in patients with several types of solid tumors demonstrated that AQ4N was well-tolerated and activated selectively in hypoxic regions in solid tumors $[82,83]$.

\subsubsection{PR-104}

PR-104 is a phosphate ester that is hydrolyzed and reduced under hypoxic conditions to release amine (PR-104M) and hydroxyl-amine (PR-104H) nitrogen mustards [80]. Subsequently, these reactive nitrogen mustards crosslink DNA and cause cytotoxicity in cancer cells. According to a phase I/II study in patients with acute myeloid leukemia (AML) and acute lymphoblastic leukemia (ALL), 32\% of AML patients and $20 \%$ of ALL patients showed response to treatment with PR-104 (ClinicalTrials.gov NCT01037556) [84].

\subsubsection{TH-302 (evofosfamide)}

TH-302 is a 2-nitroimidazole prodrug that selectively releases bromo-isophosphoramide which crosslinks DNA under hypoxic conditions [80]. A preclinical study showed that in vivo treatment of the 5T33MM mouse model of multiple myeloma with TH-302 induced apoptosis of tumor cells within the bone microenvironment [85]. Furthermore, Liapis et al. demonstrated that TH-302 significantly delayed the growth of human breast cancer MDA-MB-231-TXSA cells in mouse tibiae [86]. The combination with paclitaxel exhibited greater inhibitory effects. However, phase III studies in advanced unresectable or metastatic pancreatic adenocarcinoma (ClinicalTrials.gov NCT01746979) and in soft tissue sarcoma (ClinicalTrials.gov NCT01440088) reported that TH-302 did not achieve primary overall survival endpoints in combination with doxorubicin or gemcitabine [87]. 


\subsubsection{TOP3}

TOP3 is a fusion protein that comprises of the protein transduction domain embedded in the human immunodeficiency virus (HIV)-TAT protein, ODD, and procaspase-3 [88]. TOP3 is degraded under normoxic conditions; however, under hypoxic conditions, the protein is stabilized and causes caspase-3-induced cell death. Furthermore, because HIV-TAT fusion proteins freely diffuse through the cell membrane, TOP3 can be delivered to tissues with compromised blood supply [89]. We reported previously that TOP3 selectively induced apoptosis in hypoxic tumor cells in vitro and significantly reduced bone metastases of MDA-MB-231 cells in mice [39].

\subsection{Targeting HIFs}

Although targeting HIFs themselves remains challenging, several clinical trials using chemotherapeutic agents, such as CRLX101 (ClinicalTrials.gov NCT02187302) [90], letrozole [91], bortezomib (ClinicalTrials.gov NCT00428545) [92], EZN-2208 (ClinicalTrials.gov NCT01251926), temsirolimus (ClinicalTrials.gov NCT00761644) [92], and topotencan (ClinicalTrials.gov NCT00436644) [93], which are expected to reduce the expression and/or transcriptional activity of HIFs, have been conducted. Some of them showed favorable results.

As an approach to directly target HIFs, miRs have been investigated at preclinical levels [94]. Several miRs are induced in response to low oxygen, the majority of which are also overexpressed in a variety of human tumors. Some of those, such as miR-26, -107 , and -210 , were shown to interfere with pro-apoptotic signaling under a hypoxic environment, suggesting a possible involvement of these miRs in tumor formation [95]. Zhou et al. reported that miR-33b targeted HIF- $1 \alpha$ and inhibited the proliferation and migration of osteosarcoma cells [96].

\section{Conclusions}

As well as tumor tissues, recent advances in imaging technology confirmed that bone is a generally hypoxic microenvironment. The studies described above collectively suggest the critical roles of hypoxia and related genes in promoting cancer metastasis; however, the specific contribution to bone metastasis remains less clear. Continued studies to further understand specific mechanisms of the roles of hypoxia in bone metastasis are clearly warranted and may likely lead to new and innovative therapeutic strategies to block and cure bone metastasis.

Funding: This work was supported by JSPS KAKENHI Grant Number 18K19656.

Conflicts of Interest: The author declares no conflict of interest.

$\begin{array}{ll}\text { Abbreviations } & \\ \text { ALL } & \text { acute lymphoblastic leukemia } \\ \text { AML } & \text { acute myeloid leukemia } \\ \text { Ang } & \text { angiopoietin } \\ \text { bMDCs } & \text { bone marrow-derived cells } \\ \text { BMSCs } & \text { cancer stem cells } \\ \text { CSCs } & \text { cytotoxic T-lymphocyte antigen-4 } \\ \text { CTLA-4 } & \text { C-X-C motif chemokine ligand 12 } \\ \text { CXCL12 } & \text { C-X-C motif chemokine receptor 4 } \\ \text { CXCR4 } & \text { disseminated tumor cells } \\ \text { DTCs } & \text { dual specificity protein phosphatase 1 } \\ \text { DUSP1 } & \text { extracellular matrix } \\ \text { ECM } & \text { epithelial-mesenchymal transition } \\ \text { EMT } & \text { estrogen receptor } \\ \text { ER } & \text { extracellular vesicles } \\ \text { EVs } & \text { forkhead box P3 } \\ \text { Foxp3 } & \end{array}$




\begin{tabular}{|c|c|}
\hline GDF & growth differentiation factor \\
\hline GLUT1 & glucose transporter 1 \\
\hline HAPs & hypoxia-activated prodrugs \\
\hline HIFs & hypoxia-inducible factors \\
\hline HIV & human immunodeficiency virus \\
\hline HMGB1 & high mobility group box-1 \\
\hline HRE & hypoxia response element \\
\hline IGFs & insulin-like growth factors \\
\hline IL & interleukin \\
\hline LIFR & leukemia inhibitory factor receptor \\
\hline LOX & lysyl oxidase \\
\hline M-CSF & macrophage colony-stimulating factor \\
\hline MDSCs & myeloid-derived suppressor cells \\
\hline $\mathrm{miR}$ & microRNA \\
\hline MMPs & matrix metalloproteinases \\
\hline NFATc1 & nuclear factor of activated T cells cytoplasmic 1 \\
\hline $\mathrm{NO}$ & nitric oxide \\
\hline OCT4 & octamer-binding transcription factor 4 \\
\hline ODD & oxygen-dependent degradation domain \\
\hline OPG & osteoprotegerin \\
\hline P4HA & prolyl-4-hydroxylase \\
\hline PD1 & programmed cell death protein 1 \\
\hline PDGF & platelet-derived growth factor \\
\hline PD-L1 & programmed death-ligand 1 \\
\hline PGF & placental growth factor \\
\hline PLOD & procollagen-lysine, 2-oxyglutarate 5-dioxygenase \\
\hline pO2 & partial pressure of oxygen \\
\hline PTHrP & parathyroid hormone-related protein \\
\hline RANKL & receptor activator of nuclear factor- $\mathrm{kB}$ ligand \\
\hline SCF & stem cell factor \\
\hline SCLC & small cell lung cancer \\
\hline SDF-1 & stromal-derived fator-1 \\
\hline SOCS3 & suppressor of cytokine signaling 3 \\
\hline SOX2 & sex determining region Y-box 2 \\
\hline SREs & skeletal-related events \\
\hline STAT3 & signal transducer and activator 3 \\
\hline TAMs & tumor-associated macrophages \\
\hline TAT & trans-activator of transcription \\
\hline TGF $\beta$ & transforming growth factor $\beta$ \\
\hline TOP3 & TAT-ODD-procaspase-3 \\
\hline VEGF & vascular endothelial growth factor \\
\hline VHL & von Hippel-Lindau \\
\hline LD & linear dichroism \\
\hline
\end{tabular}

\section{References}

1. Yoneda, T.; Hiraga, T. Crosstalk between cancer cells and bone microenvironment in bone metastasis. Biochem. Biophys. Res. Commun. 2005, 328, 679-687. [CrossRef] [PubMed]

2. Coleman, R.E. Clinical features of metastatic bone disease and risk of skeletal morbidity. Clin. Cancer Res. 2006, 12, 6243-6249. [CrossRef] [PubMed]

3. Höckel, M.; Vaupel, P. Tumor hypoxia: Definitions and current clinical, biologic, and molecular aspects. J. Natl. Cancer Inst. 2001, 93, 266-276. [CrossRef] [PubMed]

4. Keith, B.; Johnson, R.S.; Simon, M.C. HIF1 $\alpha$ and HIF2 $\alpha$ : Sibling rivalry in hypoxic tumour growth and progression. Nat. Rev. Cancer 2012, 12, 9-22. [CrossRef] [PubMed] 
5. Schito, L.; Semenza, G.L. Hypoxia-inducible factors: Master regulators of cancer progression. Trends Cancer 2016, 2, 758-770. [CrossRef] [PubMed]

6. Duan, C. Hypoxia-inducible factor 3 biology: Complexities and emerging themes. Am. J. Physiol. Cell Physiol. 2016, 310, C260-C269. [CrossRef] [PubMed]

7. Kietzmann, T.; Mennerich, D.; Dimova, E.Y. Hypoxia-inducible factors (HIFs) and phosphorylation: Impact on stability, localization, and transactivity. Front. Cell Dev. Biol. 2016, 4, 11. [CrossRef] [PubMed]

8. Rankin, E.B.; Nam, J.-M.; Giaccia, A.J. Hypoxia: Signaling the metastatic cascade. Trends Cancer 2016, 2, 295-304. [CrossRef] [PubMed]

9. Bielenberg, D.R.; Zetter, B.R. The contribution of angiogenesis to the process of metastasis. Cancer J. 2015, 21, 267-273. [CrossRef] [PubMed]

10. Sasaki, A.; Alcalde, R.E.; Nishiyama, A.; Lim, D.D.; Mese, H.; Akedo, H.; Matsumura, T. Angiogenesis inhibitor TNP-470 inhibits human breast cancer osteolytic bone metastasis in nude mice through the reduction of bone resorption. Cancer Res. 1998, 58, 462-467. [PubMed]

11. Sun, C.; Li, J.; Wang, B.; Shangguan, J.; Figini, M.; Shang, N.; Pan, L.; Zhang, Z. Tumor angiogenesis and bone metastasis-Correlation in invasive breast carcinoma. J. Immunol. Methods 2018, 452, 46-52. [CrossRef] [PubMed]

12. Brabletz, T.; Kalluri, R.; Nieto, M.A.; Weinberg, R.A. EMT in cancer. Nat. Rev. Cancer 2018, 18, $128-134$. [CrossRef] [PubMed]

13. Croset, M.; Goehrig, D.; Frackowiak, A.; Bonnelye, E.; Ansieau, S.; Puisieux, A.; Clézardin, P. TWIST1 expression in breast cancer cells facilitates bone metastasis formation. J. Bone Miner. Res. 2014, 29, 1886-1899. [CrossRef] [PubMed]

14. Liu, Y.; Zhang, N.; Wang, Y.; Xu, M.; Liu, N.; Pang, X.; Cao, J.; Ma, N.; Pang, H.; Liu, L.; et al. Zinc finger E-box binding homeobox 1 promotes invasion and bone metastasis of small cell lung cancer in vitro and in vivo. Cancer Sci. 2012, 103, 1420-1428. [CrossRef] [PubMed]

15. Batlle, E.; Clevers, H. Cancer stem cells revisited. Nat. Med. 2017, 23, 1124-1134. [CrossRef] [PubMed]

16. Hiraga, T.; Ito, S.; Nakamura, H. Cancer stem-like cell marker CD44 promotes bone metastases by enhancing tumorigenicity, cell motility, and hyaluronan production. Cancer Res. 2013, 73, 4112-4122. [CrossRef] [PubMed]

17. Hiraga, T.; Ito, S.; Nakamura, H. EpCAM expression in breast cancer cells is associated with enhanced bone metastasis formation. Int. J. Cancer 2016, 138, 1698-1708. [CrossRef] [PubMed]

18. Li, Z.; Bao, S.; Wu, Q.; Wang, H.; Eyler, C.; Sathornsumetee, S.; Shi, Q.; Cao, Y.; Lathia, J.; McLendon, R.E.; et al. Hypoxia-inducible factors regulate tumorigenic capacity of glioma stem cells. Cancer Cell 2009, 15, 501-513. [CrossRef] [PubMed]

19. Conley, S.J.; Gheordunescu, E.; Kakarala, P.; Newman, B.; Korkaya, H.; Heath, A.N.; Clouthier, S.G.; Wicha, M.S. Antiangiogenic agents increase breast cancer stem cells via the generation of tumor hypoxia. Proc. Natl. Acad. Sci. USA 2012, 109, 2784-2789. [CrossRef] [PubMed]

20. Carnero, A.; Lleonart, M. The hypoxic microenvironment: A determinant of cancer stem cell evolution. BioEssays 2016, 38, S65-S74. [CrossRef] [PubMed]

21. Sosa, M.S.; Bragado, P.; Aguirre-Ghiso, J.A. Mechanisms of disseminated cancer cell dormancy: An awakening field. Nat. Rev. Cancer 2014, 14, 611-622. [CrossRef] [PubMed]

22. Schmidt-Kittler, O.; Ragg, T.; Daskalakis, A.; Granzow, M.; Ahr, A.; Blankenstein, T.J.F.; Kaufmann, M.; Diebold, J.; Arnholdt, H.; Muller, P.; et al. From latent disseminated cells to overt metastasis: Genetic analysis of systemic breast cancer progression. Proc. Natl. Acad. Sci. USA 2003, 100, 7737-7742. [CrossRef] [PubMed]

23. Fluegen, G.; Avivar-Valderas, A.; Wang, Y.; Padgen, M.R.; Williams, J.K.; Nobre, A.R.; Calvo, V.; Cheung, J.F.; Bravo-Cordero, J.J.; Entenberg, D.; et al. Phenotypic heterogeneity of disseminated tumour cells is preset by primary tumour hypoxic microenvironments. Nat. Cell Biol. 2017, 19, 120-132. [CrossRef] [PubMed]

24. Carcereri de Prati, A.; Butturini, E.; Rigo, A.; Oppici, E.; Rossin, M.; Boriero, D.; Mariotto, S. Metastatic breast cancer cells enter into dormant state and express cancer stem cells phenotype under chronic hypoxia. J. Cell. Biochem. 2017, 118, 3237-3248. [CrossRef] [PubMed]

25. Johnson, R.W.; Finger, E.C.; Olcina, M.M.; Vilalta, M.; Aguilera, T.; Miao, Y.; Merkel, A.R.; Johnson, J.R.; Sterling, J.A.; Wu, J.Y; et al. Induction of LIFR confers a dormancy phenotype in breast cancer cells disseminated to the bone marrow. Nat. Cell Biol. 2016, 18, 1078-1089. [CrossRef] [PubMed] 
26. Shao, C.; Yang, F.; Miao, S.; Liu, W.; Wang, C.; Shu, Y.; Shen, H. Role of hypoxia-induced exosomes in tumor biology. Mol. Cancer 2018, 17, 120. [CrossRef] [PubMed]

27. Inder, K.L.; Ruelcke, J.E.; Petelin, L.; Moon, H.; Choi, E.; Rae, J.; Blumenthal, A.; Hutmacher, D.; Saunders, N.A.; Stow, J.L.; et al. Cavin-1/PTRF alters prostate cancer cell-derived extracellular vesicle content and internalization to attenuate extracellular vesicle-mediated osteoclastogenesis and osteoblast proliferation. J. Extracell. Vesicles 2014, 3, 23784. [CrossRef] [PubMed]

28. Raimondi, L.; De Luca, A.; Amodio, N.; Manno, M.; Raccosta, S.; Taverna, S.; Bellavia, D.; Naselli, F.; Fontana, S.; Schillaci, O.; et al. Involvement of multiple myeloma cell-derived exosomes in osteoclast differentiation. Oncotarget 2015, 6, 13772-13789. [CrossRef] [PubMed]

29. Taverna, S.; Pucci, M.; Giallombardo, M.; Di Bella, M.A.; Santarpia, M.; Reclusa, P.; Gil-Bazo, I.; Rolfo, C.; Alessandro, R. Amphiregulin contained in NSCLC-exosomes induces osteoclast differentiation through the activation of EGFR pathway. Sci. Rep. 2017, 7, 3170. [CrossRef] [PubMed]

30. Karlsson, T.; Lundholm, M.; Widmark, A.; Persson, E. Tumor cell-derived exosomes from the prostate cancer cell line TRAMP-C1 impair osteoclast formation and differentiation. PLoS ONE 2016, 11, e0166284. [CrossRef] [PubMed]

31. Roccaro, A.M.; Sacco, A.; Maiso, P.; Azab, A.K.; Tai, Y.-T.; Reagan, M.; Azab, F.; Flores, L.M.; Campigotto, F.; Weller, E.; et al. BM mesenchymal stromal cell-derived exosomes facilitate multiple myeloma progression. J. Clin. Investig. 2013, 123, 1542-1555. [CrossRef] [PubMed]

32. Ono, M.; Kosaka, N.; Tominaga, N.; Yoshioka, Y.; Takeshita, F.; Takahashi, R.; Yoshida, M.; Tsuda, H.; Tamura, K.; Ochiya, T. Exosomes from bone marrow mesenchymal stem cells contain a microRNA that promotes dormancy in metastatic breast cancer cells. Sci. Signal. 2014, 7, 63. [CrossRef] [PubMed]

33. Hashimoto, K.; Ochi, H.; Sunamura, S.; Kosaka, N.; Mabuchi, Y.; Fukuda, T.; Yao, K.; Kanda, H.; Ae, K.; Okawa, A.; et al. Cancer-secreted hsa-miR-940 induces an osteoblastic phenotype in the bone metastatic microenvironment via targeting ARHGAP1 and FAM134A. Proc. Natl. Acad. Sci. USA 2018, 115, 2204-2209. [CrossRef] [PubMed]

34. King, H.W.; Michael, M.Z.; Gleadle, J.M. Hypoxic enhancement of exosome release by breast cancer cells. BMC Cancer 2012, 12, 421. [CrossRef] [PubMed]

35. Liu, Y.; Cao, X. Characteristics and significance of the pre-metastatic niche. Cancer Cell 2016, 30, 668-681. [CrossRef] [PubMed]

36. Wong, C.C.-L.; Gilkes, D.M.; Zhang, H.; Chen, J.; Wei, H.; Chaturvedi, P.; Fraley, S.I.; Wong, C.-M.; Khoo, U.-S.; $\mathrm{Ng}$, I.O.-L.; et al. Hypoxia-inducible factor 1 is a master regulator of breast cancer metastatic niche formation. Proc. Natl. Acad. Sci. USA 2011, 108, 16369-16374. [CrossRef] [PubMed]

37. Spencer, J.A.; Ferraro, F.; Roussakis, E.; Klein, A.; Wu, J.; Runnels, J.M.; Zaher, W.; Mortensen, L.J.; Alt, C.; Turcotte, R.; et al. Direct measurement of local oxygen concentration in the bone marrow of live animals. Nature 2014, 508, 269-273. [CrossRef] [PubMed]

38. Arnett, T.R.; Gibbons, D.C.; Utting, J.C.; Orriss, I.R.; Hoebertz, A.; Rosendaal, M.; Meghji, S. Hypoxia is a major stimulator of osteoclast formation and bone resorption. J. Cell. Physiol. 2003, 196, 2-8. [CrossRef] [PubMed]

39. Hiraga, T.; Kizaka-Kondoh, S.; Hirota, K.; Hiraoka, M.; Yoneda, T. Hypoxia and hypoxia-inducible factor-1 expression enhance osteolytic bone metastases of breast cancer. Cancer Res. 2007, 67, 4157-4163. [CrossRef] [PubMed]

40. Knowles, H. Hypoxic regulation of osteoclast differentiation and bone resorption activity. Hypoxia 2015, 3, 73. [CrossRef] [PubMed]

41. Miyauchi, Y.; Sato, Y.; Kobayashi, T.; Yoshida, S.; Mori, T.; Kanagawa, H.; Katsuyama, E.; Fujie, A.; Hao, W.; Miyamoto, K.; et al. HIF1 is required for osteoclast activation by estrogen deficiency in postmenopausal osteoporosis. Proc. Natl. Acad. Sci. USA 2013, 110, 16568-16573. [CrossRef] [PubMed]

42. Yuan, F.-L.; Xu, M.-H.; Li, X.; He, X.; Fang, W.; Dong, J. The roles of acidosis in osteoclast biology. Front. Physiol. 2016, 7, 222. [CrossRef] [PubMed]

43. Utting, J.C.; Robins, S.P.; Brandao-Burch, A.; Orriss, I.R.; Behar, J.; Arnett, T.R. Hypoxia inhibits the growth, differentiation and bone-forming capacity of rat osteoblasts. Exp. Cell Res. 2006, 312, 1693-1702. [CrossRef] [PubMed] 
44. Rankin, E.B.; Wu, C.; Khatri, R.; Wilson, T.L.S.; Andersen, R.; Araldi, E.; Rankin, A.L.; Yuan, J.; Kuo, C.J.; Schipani, E.; et al. The HIF signaling pathway in osteoblasts directly modulates erythropoiesis through the production of EPO. Cell 2012, 149, 63-74. [CrossRef] [PubMed]

45. Regan, J.N.; Lim, J.; Shi, Y.; Joeng, K.S.; Arbeit, J.M.; Shohet, R.V.; Long, F. Up-regulation of glycolytic metabolism is required for HIF1 $\alpha$-driven bone formation. Proc. Natl. Acad. Sci. USA 2014, 111, 8673-8678. [CrossRef] [PubMed]

46. Devignes, C.-S.; Aslan, Y.; Brenot, A.; Devillers, A.; Schepers, K.; Fabre, S.; Chou, J.; Casbon, A.-J.; Werb, Z.; Provot, S. HIF signaling in osteoblast-lineage cells promotes systemic breast cancer growth and metastasis in mice. Proc. Natl. Acad. Sci. USA 2018, 115, E992-E1001. [CrossRef] [PubMed]

47. Walsh, M.C.; Takegahara, N.; Kim, H.; Choi, Y. Updating osteoimmunology: Regulation of bone cells by innate and adaptive immunity. Nat. Rev. Rheumatol. 2018, 14, 146-156. [CrossRef] [PubMed]

48. Terashima, A.; Takayanagi, H. Overview of osteoimmunology. Calcif. Tissue Int. 2018, 102, 503-511. [CrossRef] [PubMed]

49. Arron, J.R.; Choi, Y. Bone versus immune system. Nature 2000, 408, 535-536. [CrossRef] [PubMed]

50. Binnewies, M.; Roberts, E.W.; Kersten, K.; Chan, V.; Fearon, D.F.; Merad, M.; Coussens, L.M.; Gabrilovich, D.I.; Ostrand-Rosenberg, S.; Hedrick, C.C.; et al. Understanding the tumor immune microenvironment (TIME) for effective therapy. Nat. Med. 2018, 24, 541-550. [CrossRef] [PubMed]

51. LaGory, E.L.; Giaccia, A.J. The ever-expanding role of HIF in tumour and stromal biology. Nat. Cell Biol. 2016, 18, 356-365. [CrossRef] [PubMed]

52. Qian, B.-Z.; Pollard, J.W. Macrophage diversity enhances tumor progression and metastasis. Cell 2010, 141, 39-51. [CrossRef] [PubMed]

53. Biswas, S.K.; Mantovani, A. Macrophage plasticity and interaction with lymphocyte subsets: Cancer as a paradigm. Nat. Immunol. 2010, 11, 889-896. [CrossRef] [PubMed]

54. Huber, R.; Meier, B.; Otsuka, A.; Fenini, G.; Satoh, T.; Gehrke, S.; Widmer, D.; Levesque, M.P.; Mangana, J.; Kerl, K.; et al. Tumour hypoxia promotes melanoma growth and metastasis via High Mobility Group Box-1 and M2-like macrophages. Sci. Rep. 2016, 6, 29914. [CrossRef] [PubMed]

55. Laoui, D.; Van Overmeire, E.; Di Conza, G.; Aldeni, C.; Keirsse, J.; Morias, Y.; Movahedi, K.; Houbracken, I.; Schouppe, E.; Elkrim, Y.; et al. Tumor hypoxia does not drive differentiation of tumor-associated macrophages but rather fine-tunes the M2-like macrophage population. Cancer Res. 2014, 74, 24-30. [CrossRef] [PubMed]

56. Colegio, O.R.; Chu, N.-Q.; Szabo, A.L.; Chu, T.; Rhebergen, A.M.; Jairam, V.; Cyrus, N.; Brokowski, C.E.; Eisenbarth, S.C.; Phillips, G.M.; et al. Functional polarization of tumour-associated macrophages by tumour-derived lactic acid. Nature 2014, 513, 559-563. [CrossRef] [PubMed]

57. Doedens, A.L.; Stockmann, C.; Rubinstein, M.P.; Liao, D.; Zhang, N.; DeNardo, D.G.; Coussens, L.M.; Karin, M.; Goldrath, A.W.; Johnson, R.S. Macrophage expression of hypoxia-inducible factor-1 $\alpha$ suppresses T-cell function and promotes tumor progression. Cancer Res. 2010, 70, 7465-7475. [CrossRef] [PubMed]

58. Veglia, F.; Perego, M.; Gabrilovich, D. Myeloid-derived suppressor cells coming of age. Nat. Immunol. 2018, 19, 108-119. [CrossRef] [PubMed]

59. Corzo, C.A.; Condamine, T.; Lu, L.; Cotter, M.J.; Youn, J.-I.; Cheng, P.; Cho, H.-I.; Celis, E.; Quiceno, D.G.; Padhya, T.; et al. HIF- $1 \alpha$ regulates function and differentiation of myeloid-derived suppressor cells in the tumor microenvironment. J. Exp. Med. 2010, 207, 2439-2453. [CrossRef] [PubMed]

60. Noman, M.Z.; Desantis, G.; Janji, B.; Hasmim, M.; Karray, S.; Dessen, P.; Bronte, V.; Chouaib, S. PD-L1 is a novel direct target of HIF-1 $\alpha$, and its blockade under hypoxia enhanced MDSC-mediated T cell activation. J. Exp. Med. 2014, 211, 781-790. [CrossRef] [PubMed]

61. Shitara, K.; Nishikawa, H. Regulatory T cells: A potential target in cancer immunotherapy. Ann. N. Y. Acad. Sci. 2018, 1417, 104-115. [CrossRef] [PubMed]

62. Facciabene, A.; Peng, X.; Hagemann, I.S.; Balint, K.; Barchetti, A.; Wang, L.P.; Gimotty, P.A.; Gilks, C.B.; Lal, P.; Zhang, L.; et al. Tumour hypoxia promotes tolerance and angiogenesis via CCL28 and Tregcells. Nature 2011, 475, 226-230. [CrossRef] [PubMed]

63. Clambey, E.T.; McNamee, E.N.; Westrich, J.A.; Glover, L.E.; Campbell, E.L.; Jedlicka, P.; de Zoeten, E.F.; Cambier, J.C.; Stenmark, K.R.; Colgan, S.P.; et al. Hypoxia-inducible factor-1 alpha-dependent induction of FoxP3 drives regulatory T-cell abundance and function during inflammatory hypoxia of the mucosa. Proc. Natl. Acad. Sci. USA 2012, 109, E2784-E2793. [CrossRef] [PubMed] 
64. Vaupel, P.; Höckel, M.; Mayer, A. Detection and characterization of tumor hypoxia using pO 2 histography. Antioxid. Redox Signal. 2007, 9, 1221-1236. [CrossRef] [PubMed]

65. Raleigh, J.A.; Calkins-Adams, D.P.; Rinker, L.H.; Ballenger, C.A.; Weissler, M.C.; Fowler, W.C.; Novotny, D.B.; Varia, M.A. Hypoxia and vascular endothelial growth factor expression in human squamous cell carcinomas using pimonidazole as a hypoxia marker. Cancer Res. 1998, 58, 3765-3768. [PubMed]

66. Woelfle, U.; Cloos, J.; Sauter, G.; Riethdorf, L.; Jänicke, F.; van Diest, P.; Brakenhoff, R.; Pantel, K. Molecular signature associated with bone marrow micrometastasis in human breast cancer. Cancer Res. 2003, 63, 5679-5684. [PubMed]

67. Lu, X.; Yan, C.H.; Yuan, M.; Wei, Y.; Hu, G.; Kang, Y. In vivo dynamics and distinct functions of hypoxia in primary tumor growth and organotropic metastasis of breast cancer. Cancer Res. 2010, 70, 3905-3914. [CrossRef] [PubMed]

68. Guise, T.A.; Yin, J.J.; Taylor, S.D.; Kumagai, Y.; Dallas, M.; Boyce, B.F.; Yoneda, T.; Mundy, G.R. Evidence for a causal role of parathyroid hormone-related protein in the pathogenesis of human breast cancer-mediated osteolysis. J. Clin. Investig. 1996, 98, 1544-1549. [CrossRef] [PubMed]

69. Manisterski, M.; Golan, M.; Amir, S.; Weisman, Y.; Mabjeesh, N.J. Hypoxia induces PTHrP gene transcription in human cancer cells through the HIF-2 $\alpha$. Cell Cycle 2010, 9, 3723-3729. [CrossRef] [PubMed]

70. Dunn, L.K.; Mohammad, K.S.; Fournier, P.G.J.; McKenna, C.R.; Davis, H.W.; Niewolna, M.; Peng, X.H.; Chirgwin, J.M.; Guise, T.A. Hypoxia and TGF- $\beta$ drive breast cancer bone metastases through parallel signaling pathways in tumor cells and the bone microenvironment. PLoS ONE 2009, 4, e6896. [CrossRef] [PubMed]

71. Cox, T.R.; Gartland, A.; Erler, J.T. Lysyl oxidase, a targetable secreted molecule involved in cancer metastasis. Cancer Res. 2016, 76, 188-192. [CrossRef] [PubMed]

72. Erler, J.T.; Bennewith, K.L.; Nicolau, M.; Dornhöfer, N.; Kong, C.; Le, Q.-T.; Chi, J.-T.A.; Jeffrey, S.S.; Giaccia, A.J. Lysyl oxidase is essential for hypoxia-induced metastasis. Nature 2006, 440, 1222-1226. [CrossRef] [PubMed]

73. Erler, J.T.; Bennewith, K.L.; Cox, T.R.; Lang, G.; Bird, D.; Koong, A.; Le, Q.-T.; Giaccia, A.J. Hypoxia-induced lysyl oxidase is a critical mediator of bone marrow cell recruitment to form the premetastatic niche. Cancer Cell 2009, 15, 35-44. [CrossRef] [PubMed]

74. Cox, T.R.; Rumney, R.M.H.; Schoof, E.M.; Perryman, L.; Høye, A.M.; Agrawal, A.; Bird, D.; Latif, N.A.; Forrest, H.; Evans, H.R.; et al. The hypoxic cancer secretome induces pre-metastatic bone lesions through lysyl oxidase. Nature 2015, 522, 106-110. [CrossRef] [PubMed]

75. Reynaud, C.; Ferreras, L.; Di Mauro, P.; Kan, C.; Croset, M.; Bonnelye, E.; Pez, F.; Thomas, C.; Aimond, G.; Karnoub, A.E.; et al. Lysyl oxidase is a strong determinant of tumor cell colonization in bone. Cancer Res. 2017, 77, 268-278. [CrossRef] [PubMed]

76. Feres-Filho, E.J.; Choi, Y.J.; Han, X.; Takala, T.E.; Trackman, P.C. Pre- and post-translational regulation of lysyl oxidase by transforming growth factor-beta 1 in osteoblastic MC3T3-E1 cells. J. Biol. Chem. 1995, 270, 30797-30803. [CrossRef] [PubMed]

77. Bondareva, A.; Downey, C.M.; Ayres, F.; Liu, W.; Boyd, S.K.; Hallgrimsson, B.; Jirik, F.R. The lysyl oxidase inhibitor, beta-aminopropionitrile, diminishes the metastatic colonization potential of circulating breast cancer cells. PLoS ONE 2009, 4, e5620. [CrossRef] [PubMed]

78. Tsukasaki, M.; Hamada, K.; Okamoto, K.; Nagashima, K.; Terashima, A.; Komatsu, N.; Win, S.J.; Okamura, T.; Nitta, T.; Yasuda, H.; et al. LOX fails to substitute for RANKL in osteoclastogenesis. J. Bone Miner. Res. 2017, 32, 434-439. [CrossRef] [PubMed]

79. Phillips, R.M. Targeting the hypoxic fraction of tumours using hypoxia-activated prodrugs. Cancer Chemother. Pharmacol. 2016, 77, 441-457. [CrossRef] [PubMed]

80. Baran, N.; Konopleva, M. Molecular pathways: Hypoxia-activated prodrugs in cancer therapy. Clin. Cancer Res. 2017, 23, 2382-2390. [CrossRef] [PubMed]

81. Patterson, L.H.; McKeown, S.R. AQ4N: A new approach to hypoxia-activated cancer chemotherapy. Br. J. Cancer 2000, 83, 1589-1593. [CrossRef] [PubMed]

82. Papadopoulos, K.P.; Goel, S.; Beeram, M.; Wong, A.; Desai, K.; Haigentz, M.; Milian, M.L.; Mani, S.; Tolcher, A.; Lalani, A.S.; et al. A phase 1 open-label, accelerated dose-escalation study of the hypoxia-activated prodrug AQ4N in patients with advanced malignancies. Clin. Cancer Res. 2008, 14, 7110-7115. [CrossRef] [PubMed] 
83. Albertella, M.R.; Loadman, P.M.; Jones, P.H.; Phillips, R.M.; Rampling, R.; Burnet, N.; Alcock, C.; Anthoney, A.; Vjaters, E.; Dunk, C.R.; et al. Hypoxia-selective targeting by the bioreductive prodrug AQ4N in patients with solid tumors: Results of a phase I study. Clin. Cancer Res. 2008, 14, 1096-1104. [CrossRef] [PubMed]

84. Konopleva, M.; Thall, P.F.; Yi, C.A.; Borthakur, G.; Coveler, A.; Bueso-Ramos, C.; Benito, J.; Konoplev, S.; Gu, Y.; Ravandi, F.; et al. Phase I/II study of the hypoxia-activated prodrug PR104 in refractory/relapsed acute myeloid leukemia and acute lymphoblastic leukemia. Haematologica 2015, 100, 927-934. [CrossRef] [PubMed]

85. Hu, J.; Handisides, D.R.; Van Valckenborgh, E.; De Raeve, H.; Menu, E.; Vande Broek, I.; Liu, Q.; Sun, J.D.; Van Camp, B.; Hart, C.P.; et al. Targeting the multiple myeloma hypoxic niche with TH-302, a hypoxia-activated prodrug. Blood 2010, 116, 1524-1527. [CrossRef] [PubMed]

86. Liapis, V.; Zinonos, I.; Labrinidis, A.; Hay, S.; Ponomarev, V.; Panagopoulos, V.; Zysk, A.; Denichilo, M.; Ingman, W.; Atkins, G.J.; et al. Anticancer efficacy of the hypoxia-activated prodrug evofosfamide (TH-302) in osteolytic breast cancer murine models. Cancer Med. 2016, 5, 534-545. [CrossRef] [PubMed]

87. Hunter, F.W.; Wouters, B.G.; Wilson, W.R. Hypoxia-activated prodrugs: Paths forward in the era of personalised medicine. Br. J. Cancer 2016, 114, 1071-1077. [CrossRef] [PubMed]

88. Harada, H.; Hiraoka, M.; Kizaka-Kondoh, S. Antitumor effect of TAT-oxygen-dependent degradation-caspase-3 fusion protein specifically stabilized and activated in hypoxic tumor cells. Cancer Res. 2002, 62, 2013-2018. [PubMed]

89. Kizaka-Kondoh, S.; Inoue, M.; Harada, H.; Hiraoka, M. Tumor hypoxia: A target for selective cancer therapy. Cancer Sci. 2003, 94, 1021-1028. [CrossRef] [PubMed]

90. Voss, M.H.; Hussain, A.; Vogelzang, N.; Lee, J.L.; Keam, B.; Rha, S.Y.; Vaishampayan, U.; Harris, W.B.; Richey, S.; Randall, J.M.; et al. A randomized phase II trial of CRLX101 in combination with bevacizumab versus standard of care in patients with advanced renal cell carcinoma. Ann. Oncol. 2017, 28, 2754-2760. [CrossRef] [PubMed]

91. Generali, D.; Berruti, A.; Cappelletti, M.R.; Zanotti, L.; Brugnoli, G.; Forti, M.; Bedussi, F.; Vailati, M.E.; Milani, M.; Strina, C.; et al. Effect of primary letrozole treatment on tumor expression of mTOR and HIF-1 $\alpha$ and relation to clinical response. JNCI Monogr. 2015, 2015, 64-66. [CrossRef] [PubMed]

92. Moroney, J.; Fu, S.; Moulder, S.; Falchook, G.; Helgason, T.; Levenback, C.; Hong, D.; Naing, A.; Wheler, J.; Kurzrock, R. Phase I Study of the antiangiogenic antibody bevacizumab and the mTOR/hypoxia-inducible factor inhibitor temsirolimus combined with liposomal doxorubicin: Tolerance and biological activity. Clin. Cancer Res. 2012, 18, 5796-5805. [CrossRef] [PubMed]

93. Weroha, S.J.; Oberg, A.L.; Ziegler, K.L.A.; Dakhilm, S.R.; Rowland, K.M.; Hartmann, L.C.; Moore, D.F.; Keeney, G.L.; Peethambaram, P.P.; Haluska, P. Phase II trial of lapatinib and topotecan (LapTop) in patients with platinum-refractory/resistant ovarian and primary peritoneal carcinoma. Gynecol. Oncol. 2011, 122, 116-120. [CrossRef] [PubMed]

94. Rupaimoole, R.; Slack, F.J. MicroRNA therapeutics: Towards a new era for the management of cancer and other diseases. Nat. Rev. Drug Discov. 2017, 16, 203-222. [CrossRef] [PubMed]

95. Kulshreshtha, R.; Ferracin, M.; Wojcik, S.E.; Garzon, R.; Alder, H.; Agosto-Perez, F.J.; Davuluri, R.; Liu, C.-G.; Croce, C.M.; Negrini, M.; et al. A microRNA signature of hypoxia. Mol. Cell. Biol. 2007, 27, 1859-1867. [CrossRef] [PubMed]

96. Zhou, Y.; Yang, C.; Wang, K.; Liu, X.; Liu, Q. MicroRNA-33b inhibits the proliferation and migration of osteosarcoma cells via targeting hypoxia-inducible factor-1 $\alpha$. Oncol. Res. Featur. Preclin. Clin. Cancer Ther. 2017, 25, 397-405. [CrossRef] [PubMed]

(C) 2018 by the author. Licensee MDPI, Basel, Switzerland. This article is an open access article distributed under the terms and conditions of the Creative Commons Attribution (CC BY) license (http:/ / creativecommons.org/licenses/by/4.0/). 